\author{
Maria Górnicka* \\ ORCID: 0000-0002-0089-5030 \\ Uniwersytet Wrocławski
}

DOI: $10.19195 / 1733-5779.26 .3$

\title{
Osoba starsza jako pokrzywdzony w postępowaniu przed sądem karnym
}

\author{
JEL Classification: K400
}

Słowa kluczowe: prawo, postępowanie karne, sąd, pokrzywdzony, ofiara, osoba starsza

Keywords: law, criminal proceedings, court, aggrieved party, victim, elderly person

Abstrakt: Celem artykułu jest wykazanie, że szczególne regulacje dotyczące sytuacji osoby starszej jako pokrzywdzonego w postępowaniu przed sądem karnym są fragmentaryczne i niewystarczające, warto więc, aby zostały rozszerzone. Zostanie to dokonane najpierw poprzez zwrócenie uwagi na pojęcie i status pokrzywdzonej osoby starszej w postępowaniu przed sądem karnym oraz opis obecnych jej uprawnień w podziale na pokrzywdzonego bez statusu strony i pokrzywdzonego-stronę. Całość zostanie zwieńczona propozycją regulacji ułatwiających korzystanie $\mathrm{z}$ uprawnień osobom starszym jako pokrzywdzonym w postępowaniu przed sądem karnym.

\section{Elderly person as an aggrieved party in the criminal court proceedings}

Abstract: The aim of this article is to demonstrate that the special regulations concerning the situation of an elderly person as an aggrieved party in the criminal court proceedings are rudimentary and inadequate, so it is worth to have been extended. This will be done at first by drawing attention to the definition and status of the aggrieved elderly person in the criminal court proceedings, and a description of its current permissions divided on a victim without a party status and a victim with a party status. Then the whole is topped with a proposal for regulations to facilitate the use of the permissions of the elderly persons as an aggrieved party in the criminal court proceedings.

* Opiekun naukowy (Scientific Tutor) — Jerzy Skorupka 


\section{Wstęp}

Obecna tendencja demograficzna dotycząca starzenia się społeczeństwa prawdopodobnie spowoduje coraz większą liczbę osób starszych pokrzywdzonych przestępstwem. Organizowanie akcji, kampanii i szkoleń wpływa na większą świadomość prawną ludzi starszych, którzy, jeśli będą zgłaszać więcej przestępstw popełnianych na ich szkodę, będą coraz częściej występować jako pokrzywdzeni w postępowaniu karnym: w pierwszym stadium - przygotowawczym — przed organem postępowania przygotowawczego, a w drugim stadium — sądowym przed sądem karnym. O stadium przygotowawczym mówi się więcej, zwracając uwagę na rolę procedury „Niebieskiej Karty” czy szczególnych programów policyjnych dotyczących pomocy ofiarom przemocy w rodzinie lub ofiarom przestępstw „na wnuczka". Stadium sądowe do tej pory wydaje się niezauważane, a jest ważne, ponieważ to w nim, niezależnie od tego, w której instancji, dochodzi do ostatecznego rozstrzygnięcia postępowania. Taki stan faktyczny zwraca uwagę na zagadnienie regulacji sytuacji osób starszych jako pokrzywdzonych w postępowaniu przed sądem karnym.

Artykuł ma na celu wykazanie, że szczególne regulacje dotyczące sytuacji osoby starszej jako pokrzywdzonego w postępowaniu przed sądem karnym są szczątkowe i niewystarczające, warto więc je rozszerzyć. Zostanie to zrealizowane przede wszystkim poprzez zwrócenie uwagi na pojęcie i status pokrzywdzonej osoby starszej w postępowaniu przed sądem karnym oraz opis obecnych jej uprawnień, zwłaszcza związanych z nieporadnością uczestników postępowania karnego w ogólności, wynikających z uregulowań ustawy z dnia 6 czerwca 1997 roku Kodeks postępowania karnego ${ }^{2}$ (dalej „k.p.k.”), w podziale na pokrzywdzonego bez statusu strony i pokrzywdzonego-stronę. Pominięte zostaną obowiązki i prawa pokrzywdzonej osoby starszej występującej przed sądem jako świadek. Całość zostanie zwieńczona propozycją regulacji gwarantujących dodatkowo pozycję osób starszych jako pokrzywdzonych w postępowaniu przed sądem karnym. Aby zrealizować cel opracowania, wykorzystano metodę dogmatyczno-prawną.

\section{Pojęcie pokrzywdzonej osoby starszej}

Przedmiot niniejszej pracy składa się z dwóch części stanowiących osobne pojęcia: ,pokrzywdzony” i „osoba starsza”. Dopiero zestawienie ich definicji daje pełny obraz całościowego pojęcia ,pokrzywdzonej osoby starszej”.

Odnosząc się do pojęcia „pokrzywdzony”, należy zaznaczyć, że dopuszczenie do procesu podmiotu pokrzywdzonego musi dotyczyć jedynie osób spełniających wymagania opisane w definicji pokrzywdzonego, określonej w art. 40 k.p.k. — nie

\footnotetext{
1 Por. M. Halicka, J. Halicki, Przemoc wobec ludzi starych, Białystok 2010, s. 281-287.

2 Tekst jedn. Dz.U. z 2016 r., poz. 1749 ze zm.
} 
wystarcza więc sam fakt jakiegokolwiek pokrzywdzenia. Trzeba także od razu wyjaśnić, że do osób starszych będą się odnosić jedynie unormowania kodeksowe o pokrzywdzonym jako osobie fizycznej. Pokrzywdzonym w tym wypadku jest osoba fizyczna, której dobro prawne zostało bezpośrednio naruszone lub zagrożone przez przestępstwo. Na pojęcie pokrzywdzonej osoby fizycznej składają się zatem jeszcze takie elementy, jak ,dobro prawne” naruszone lub zagrożone przez przestępstwo oraz ,bezpośredniość” tego naruszenia lub narażenia. Elementy te należy ustalić według przepisów prawa karnego materialnego, które ostatecznie określą w danym wypadku, kto jest pokrzywdzonym ${ }^{3}$.

By dopełnić określenie przedmiotu niniejszych rozważań, należałoby do definicji ,pokrzywdzonego” dodać jeszcze kryterium wieku i określić je wprost w liczbie lat. To prowadzi do wyjaśnienia drugiego z pojęć składających się na definicję ,pokrzywdzonej osoby starszej”. Kodeks postępowania karnego nie wypowiada się na ten temat, lecz w polskim prawie można znaleźć definicję legalną osoby starszej w ustawie z dnia 11 września 2015 roku o osobach starszych 4 . Skoro ustawa ta kompleksowo określa zakres, podmioty i źródła finansowania, monitorowania i przedstawiania informacji o sytuacji osób starszych, to uregulowana w niej definicja znajdzie zastosowanie również do sytuacji osób starszych w postępowaniu karnym. Zgodnie z jej art. 4 pkt 1 osobą starszą jest osoba, która ukończyła 60. rok życia.

Ostatecznie pokrzywdzoną osobą straszą jest osoba fizyczna w wieku powyżej 60 lat, której dobro prawne zostało bezpośrednio naruszone lub zagrożone przez przestępstwo. Należy zaznaczyć, że nie jest to każda osoba starsza, która ma subiektywne poczucie pokrzywdzenia, lecz tylko taka osoba starsza, która spełnia kodeksowe warunki uznania za pokrzywdzoną osobę starszą.

Opis pokrzywdzonej osoby starszej byłby niepełny, gdyby nie odniesiono się do pozaustawowych cech ją charakteryzujących, wpływających na prowadzenie sądowego postępowania karnego. Wszak pokrzywdzone osoby starsze nie mogą być wykluczane i dyskryminowane ze względu na wiek przez sądy prowadzące postępowanie, co może wiązać się ze szczególnym traktowaniem. Przede wszystkim pokrzywdzone osoby starsze powinny być traktowane godnie niezależnie od wieku, ponieważ godność jest źródłem wszelkich innych praw człowieka ${ }^{5}$, także prawa do sądu i rzetelnego procesu wynikających z art. 45 Konstytucji Rzeczypospolitej Polskiej z dnia 2 kwietnia 1997 roku$^{6}$, art. 6 Europejskiej Konwencji o Ochronie Praw Człowieka i Podstawowych Wolności sporządzonej w Rzymie dnia 4 listopada 1950 roku $^{7}$ oraz z art. 14 Międzynarodowego Paktu Praw Oby-

\footnotetext{
3 Proces karny, red. J. Skorupka, Warszawa 2017, s. 306.

4 Dz.U. poz. 1705.

5 B. Mikołajczyk, Międzynarodowa ochrona praw osób starszych, Warszawa 2012, s. 101.

6 Dz.U. Nr 78, poz. 483 ze zm.

7 Dz.U. z 1993 r. Nr 61, poz. 284.
} 
watelskich i Politycznych otwartego do podpisu w Nowym Jorku dnia 19 grudnia 1966 roku $^{8}$. Także Zgromadzenie Ogólne ONZ wydało rezolucję nr 46/91, zawierającą Zasady działania ONZ na rzecz osób starszych ${ }^{9}$. Na szczeblu unijnym zasadę niedyskryminacji zawarto $\mathrm{w}$ art. 2 i art. 3 Traktatu o Unii Europejskiej z dnia 7 lutego 1992 roku $^{10}$ oraz w art. 10, art. 19 i art. 21 Traktatu o funkcjonowaniu Unii Europejskiej z dnia 25 marca 1957 roku $^{11}$ i art. 21 Karty Praw Podstawowych $\mathrm{z}$ dnia 7 grudnia 2000 roku, podpisanej ponownie dnia 12 grudnia $2007 \mathrm{roku}^{12}$ w dwóch ostatnich aktach prawnych dookreślono, że kryterium dyskryminacji może być także wiek. W Polsce nie wyodrębnia się gałęzi prawa zajmującej się osobami starszymi, istnieją jednak poszczególne przepisy dotyczące ich spraw ${ }^{13}$. Takie przepisy powinny zostać $\mathrm{w}$ większym zakresie wprowadzone również do kodeksu postępowania karnego, oprócz art. 51 § 3 k.p.k., dotyczącego możliwości wykonywania praw pokrzywdzonego nieporadnego ze względu na wiek przez osobę, pod której pieczą pokrzywdzony pozostaje. Wiek starszy nie powinien być przeszkodą we wzięciu udziału w postępowaniu karnym, nawet jeśli łączy się z niepełnosprawnością. Należy usunąć wszelkie bariery w ograniczeniu korzystania z prawa do sądu przez ludzi starszych. Ponadto sądy powinny brać pod uwagę to, że pokrzywdzone osoby starsze bardziej niż ludzie młodzi są wrażliwe na krzywdę, również ze strony organu ${ }^{14}$. W interesie osób starszych jest także rozpatrywanie spraw w rozsądnym terminie. Czas ten powinien być konfrontowany z podeszłym wiekiem ofiary, która może nie doczekać skazania sprawcy ${ }^{15}$. Dodatkowo sądy powinny uwzględniać to, że pokrzywdzone osoby starsze często wstydzą się swojej wiktymizacji.

Tymczasem starość jest jednym z czynników ryzyka stania się ofiarą przestępstwa. Jak wynika z brytyjskich badań, często sprawcy nie podjęliby decyzji o popełnieniu przestępstwa, gdyby nie wiedzieli, że ofiara jest osobą starszą, uznawaną za łatwy cel (easy target) ${ }^{16}$, tym bardziej, że sprawcami okazują się często członkowie rodziny ${ }^{17}$. Złe traktowanie ludzi starszych objawia się pod postacią nadużyć, czyli zadawaniu krzywdy i zaniedbań, to jest zaniechania opieki i ochrony przed krzywdą ze strony innych osób ${ }^{18}$. Na forum WHO stworzono definicję

8 Dz.U. z 1977 r. Nr 38, poz. 167.

9 B. Mikołajczyk, op. cit., s. 58; tekst polski: http://www.tus.org.pl/uploads/dokumenty/zasady_dzialania_onz_na_rzecz_osob_starszych.pdf (dostęp: 10.02.2017).

10 Wersja skonsolidowana: Dz.Urz. UE z 2016 r. C, 202, s. 13.

11 Wersja skonsolidowana: Dz.Urz. UE z 2016 r. C, 202, s. 47.

12 Dz.Urz. UE z 2016 r., C, 202, s. 389.

13 B. Mikołajczyk, op. cit., s. 91.

14 Ibidem, s. 39.

15 Ibidem, s. 201.

16 Hate Crime Report 2014/2015 and 2015/16, Crown Prosecution Service, London, July 2016, s. 37.

17 B. Mikołajczyk, op. cit., s. 51.

18 M. Halicka, J. Halicki, op. cit., s. 23. 
maltretowania i wykorzystywania osób starszych: elder abuse. „Według niej jest to pojedyncze lub powtarzające się działanie, albo brak takiego działania (zaniechanie, na przykład zaniedbanie), zdarzające się w relacjach, w których należałoby oczekiwać zaufania i opieki, a które powodują krzywdę i zagrożenie dla osoby starszej"19. Ludzie starsi są preferowanymi przez przestępców ofiarami, ponieważ są najczęściej bezradni i samotni ${ }^{20}$. Z jednej strony są słabsi fizycznie, a z drugiej — posiadają skumulowane bogactwo i władzę ${ }^{21}$. Oprócz szkód fizycznych i psychicznych szczególnie dotkliwie odczuwają więc oni szkody moralne i finansowe $^{22}$. Większa, w porównaniu do ludzi młodych, wrażliwość i lęk przed wiktymizacją osób starszych wynika ze spadku fizycznej sprawności, konieczności długotrwałej rehabilitacji odbywanej często w samotności lub problemów ze znalezieniem pracy w wypadku szkód finansowych ${ }^{23}$. Powoduje to jeszcze większą izolację i wyobcowanie ludzi starszych z otoczenia, co podnosi stopień zagrożenia wiktymizacją ${ }^{24}$. Jednocześnie zachowania defensywne ludzi starszych przyczyniają się do zmniejszenia ryzyka stania się ofiarą przestępstwa ${ }^{25}$. To, czy osoby starsze rzeczywiście stają się ofiarami przestępstwa częściej niż ludzie młodzi, zależy od rodzaju czynów — dotyczy to przede wszystkim przestępstw przeciwko mieniu. Jednakże skutki wiktymizacji zawsze są dotkliwsze dla osób starszych ${ }^{26}$.

Spełnienie warunków kodeksowych uznania za pokrzywdzoną osobę starszą nie musi od razu oznaczać jej udziału w procesie karnym, szczególnie w omawianym tutaj stadium sądowym.

\section{Status pokrzywdzonej osoby starszej w postępowaniu jurysdykcyjnym}

Osiągnięcie statusu strony w postępowaniu karnym przez pokrzywdzoną osobę starszą, tak jak pokrzywdzonego w ogólności, zależy od stadium procesu. W postępowaniu przygotowawczym, zgodnie z art. 299 § 1 k.p.k., pokrzywdzony jest stroną $\mathrm{z}$ racji samego pokrzywdzenia, $\mathrm{z}$ mocy samego prawa ${ }^{27}$. To stadium nie znajduje się jednak w centrum zainteresowań niniejszego tekstu.

19 B. Mikołajczyk, op. cit., s. 51.

20 E. Bieńkowska, Osoby starsze grupa o podwyższonym stopniu ryzyka wiktymizacji, ,Ruch Prawniczy, Ekonomiczny i Socjologiczny” 1999, nr 1, s. 112.

21 Ibidem, s. 111.

22 Ibidem, s. 116.

23 J. Czapska, Zapobieganie wiktymizacji ludzi starszych, „Ruch Prawniczy, Ekonomiczny i Socjologiczny" 1999, nr 1, s. 121.

24 E. Bieńkowska, op. cit., s. 117.

25 J. Czapska, op. cit., s. 123.

26 E. Bieńkowska, op. cit., s. 116.

27 Por. W. Grzeszczyk, Kodeks postępowania karnego. Komentarz, Warszawa 2012, s. 97. 
W stadium sądowym natomiast pokrzywdzona osoba starsza być stroną nie musi, lecz jedynie może. Wszystko zależy od tego, czy spełniła ustawowe dodatkowe wymagania. W sprawach $\mathrm{z}$ oskarżenia publicznego pokrzywdzona osoba starsza może stać się stroną, jeśli będzie działała jako oskarżyciel posiłkowy subsydiarny, to jest zamiast oskarżyciela publicznego, lub oskarżyciel posiłkowy uboczny, czyli obok oskarżyciela publicznego. Sytuacja oskarżyciela posiłkowego została unormowana w art. 58 i następnych k.p.k. Nabycie statusu oskarżyciela subsydiarnego wymaga od pokrzywdzonej osoby starszej, w razie wydania przez organ podwójnego postanowienia o odmowie wszczęcia postępowania lub o umorzeniu postępowania, wniesienia aktu oskarżenia do sądu w terminie miesiąca.

Tak więc realizacja przez pokrzywdzonego uprawnienia do występowania w roli oskarżyciela posiłkowego subsydiarnego wymaga jego nieustępliwości w zakresie dążenia do zmiany negatywnego stosunku prokuratora do ścigania sprawcy przestępstwa podlegającego ściganiu w trybie oskarżenia publicznego. Ta determinacja ujawnia się w skarżeniu kolejnych postanowień prokuratorskich odmawiających ścigania sprawcy. Co niesłychanie ważne, pokrzywdzony musi uzyskać swoiste wsparcie sądu, gdyż bez uchylenia przez sąd pierwotnego postanowienia o odmowie wszczęcia lub umorzeniu postępowania przygotowawczego ulega przerwaniu łańcuch zaszłości procesowych wiodących do subsydiarnego oskarżenia posiłkowego ${ }^{28}$.

Status oskarżyciela posiłkowego ubocznego pokrzywdzona osoba starsza uzyskuje wraz ze złożeniem, aż do rozpoczęcia przewodu sądowego na rozprawie głównej, oświadczenia, że będzie działała w charakterze oskarżyciela posiłkowego ${ }^{29}$. W sprawach z oskarżenia prywatnego natomiast pokrzywdzona osoba starsza może stać się stroną, wnosząc i popierając akt oskarżenia jako oskarżyciel prywatny lub popierając aż do rozpoczęcia przewodu sądowego na rozprawie głównej akt oskarżenia wniesiony przez innego oskarżyciela prywatnego ${ }^{30}$. Pozycję oskarżyciela prywatnego regulują art. 59 i następne k.p.k. Terminy, o których była mowa, czyli miesiąc do złożenia aktu oskarżenia, lub rozpoczęcie przewodu sądowego na rozprawie głównej są nieprzywracalne, co może spowodować wykluczenie z postępowania karnego jako strony pokrzywdzonego ze zmniejszoną aktywnością intelektualną lub po prostu nierozumiejącego pouczeń o procedurach. Jednocześnie interes pokrzywdzonego, w zakresie interesu społecznego, powinien być reprezentowany przez oskarżyciela publicznego.

W postępowaniu sądowym pokrzywdzona osoba starsza może więc działać jako strona, występując w roli oskarżyciela posiłkowego lub prywatnego, albo korzystać z uprawnień, jakie ustawa nadaje jej w konkretnej sytuacji procesowej ${ }^{31}$.

28 Por. S.M. Przyjemski, Pokrzywdzony w roli oskarżyciela positkowego, ,Wojskowy Przegląd Prawniczy" 2005, nr 3, s. 64.

29 Por. L.K. Paprzycki, Prawa i obowiazki pokrzywdzonego w postępowaniu przed sadem karnym pierwszej instancji - zarys problematyki, „Palestra” 2000, nr 2-3, s. 35.

30 Ibidem, s. 37.

31 Por. W. Grzeszczyk, op. cit., s. 97. 


\section{Uprawnienia pokrzywdzonej osoby starszej bez statusu strony}

Pokrzywdzonej osobie starszej przysługują uprawnienia pokrzywdzonego w procesie przed sądem karnym. Jeśli nie jest stroną, może skorzystać z uprawnień przyznanych pokrzywdzonemu niezależnie od tego, czy posiada status strony, czy nie.

Opis uprawnień pokrzywdzonej osoby starszej rozpocznie się od bliższej analizy jedynego przepisu kodeksu postępowania karnego odnoszącego się wprost do uprawnień pokrzywdzonej osoby starszej. Chodzi tutaj o art. $51 \S 3$ k.p.k., zgodnie z którym jeżeli pokrzywdzonym jest osoba nieporadna, w szczególności ze względu na wiek i stan zdrowia, jego prawa może wykonywać osoba, pod której pieczą pokrzywdzony pozostaje ${ }^{32}$. Oznacza to, że osoba, pod której stałą pieczą pokrzywdzony pozostaje, może dokonywać czynności procesowych za pokrzywdzonego z mocy upoważnienia ustawowego wynikającego z okoliczności opieki nad pokrzywdzonym, bez konieczności podpisywania dodatkowych upoważnień. Osoba, pod której pieczą pokrzywdzony pozostaje, jest jej opiekunem faktycznym, fakt opieki nie wymaga udokumentowania dodatkowym orzeczeniem sądu. Dlatego przed podjęciem czynności opiekun musi wykazać fakt opieki oraz nieporadność pokrzywdzonego ${ }^{33}$. Jako warunku wykonywania praw pokrzywdzonego, przepis nie wymaga sprawowania pieczy stałej. Okazuje się więc, że wystarczy piecza czasowa urzeczywistniana ze względu na nieporadność pokrzywdzonego ${ }^{34}$. Rozwiązanie to stanowi gwarancję wykonywania uprawnień dla pokrzywdzonego nieporadnego, który mógłby nie wiedzieć, jakich czynności procesowych i w jaki sposób może dokonywać lub kogo można do tego upoważnić i w jaki sposób dotrzeć do takiej osoby. W odróżnieniu od pokrzywdzonego ubezwłasnowolnionego, za którego czynności dokonuje jego przedstawiciel ustawowy, opiekun lub kurator pod nadzorem sądu opiekuńczego ${ }^{35}$, pokrzywdzony taki zachowuje jednak pełną zdolność do czynności prawnych ${ }^{36}$. Osoba, pod której pieczą pokrzywdzony pozostaje, może działać w procesie oprócz pokrzywdzonego, a nie zamiast niego ${ }^{37}$.

Pokrzywdzonej osobie starszej bez statusu strony, tak jak pokrzywdzonemu w ogóle, przysługuje wiele uprawnień związanych z pouczeniami i zawiadomieniami, następnie z udziałem i stawiennictwem w miejscu czynności, a także z ograniczonymi uprawnieniami do dokonywania poszczególnych czynności i możliwością ustanowienia pełnomocnika.

32 Por. D. Świecki, Czynności procesowe obrońcy i petnomocnika w sprawach karnych, Warszawa 2011, s. 42.

33 Postanowienie SN z dnia 25 września 2003 roku, III KZ 36/03, OSNwSK 2003, Nr 1, poz. 2046.

34 Por. W. Grzeszczyk, op. cit., s. 100.

35 Postanowienie SN z dnia 12 kwietnia 2016, V KK 29/16, LEX nr 2046365.

36 Por. K.T. Boratyńska, [w:] K.T. Boratyńska, A. Górski, A. Sakowicz, A. Ważny, Kodeks postępowania karnego. Komentarz, Warszawa 2012, s. 168.

${ }^{37}$ Ibidem, s. 168. 
Ogólny obowiązek pouczenia pokrzywdzonej osoby starszej przez organy procesowe, w tym sądy, wynika z art. 16 k.p.k. ${ }^{38}$ Sąd jest zobowiązany do pouczenia uczestników postępowania o ciążących obowiązkach i o przysługujących im uprawnieniach w sytuacjach, w których ustawa wprost tego wymaga. W innych wypadkach organ prowadzący postępowanie powinien to robić w miarę potrzeby. Przepis art. $16 \S 1$ k.p.k. daje gwarancję, że brak pouczenia lub mylne pouczenie, w sytuacjach, w których kodeks tego wymaga, nie może wywoływać ujemnych skutków procesowych względem uczestnika postępowania, którym jest także pokrzywdzona osoba starsza. Znaczy to, że jeśli pokrzywdzona osoba starsza nie uzyskała informacji lub uzyskała błędną, może podnieść tę okoliczność przy zaskarżaniu wydanego orzeczenia ${ }^{39}$. Jeśli nie zrozumiała ona treści pouczenia, powinna poprosić organ prowadzący sprawę o dodatkowe wyjaśnienie ${ }^{40}$. Prawem do uzyskania informacji przez pokrzywdzoną osobę starszą o nieco innym charakterze jest wynikające $z$ art. $253 \S 3$ k.p.k. zawiadomienie o uchyleniu, nieprzedłużeniu lub zmianie tymczasowego aresztowania na inny środek zapobiegawczy, jak również o ucieczce oskarżonego $\mathrm{z}$ aresztu śledczego ${ }^{41}$. Udzielenie informacji nie nastąpi, jeśli pokrzywdzony oświadczy, że z takiego uprawnienia rezygnuje. Pokrzywdzona osoba starsza ma także prawo do zawiadomienia o terminach posiedzeń, w których ustawa przyznaje wyraźnie prawo do wzięcia udziału, stosownie do art. 96 k.p.k., oraz zawiadomienia o terminie rozprawy co najmniej w zakresie przestępstw zagrożonych karą do piętnastu lat pozbawienia wolności, czyli takich, w ramach których można złożyć wniosek o dobrowolne poddanie się karze na podstawie art. $387 \S 2$ k.p.k. ${ }^{42}$

To wszystko łączy się z uprawnieniami pokrzywdzonej osoby starszej bez statusu strony do udziału i stawiennictwa w określonych przez ustawę posiedzeniach i rozprawie. Pokrzywdzony taki ma prawo do udziału w posiedzeniach:

1) w przedmiocie warunkowego umorzenia postępowania (art. 341 k.p.k.),

2) w przedmiocie skazania bez przeprowadzenia rozprawy w wyniku złożenia wniosku w trybie art. $335 \S 1$ k.p.k. oraz aktu oskarżenia wraz z wnioskiem w trybie art. 335 § 2 k.p.k.,

3) w przedmiocie wniosku oskarżonego skierowanego w trybie art. 338a k.p.k. ${ }^{43}$

Pokrzywdzona osoba starsza, również niezależnie od tego, czy ma ona status strony, czy nie, stosownie do art. $384 \S 2$ k.p.k. ma prawo wziąć udział w roz-

38 Por. E. Bieńkowska, L. Mazowiecka, Uprawnienia pokrzywdzonego przestęstwem, Warszawa 2009, s. 31.

39 Ibidem, s. 31.

40 Ibidem, s. 32.

41 Ibidem.

42 Por. A. Ziębiński, Prawo pokrzywdzonego do wzięcia udziału w rozprawie, ,Monitor Prawniczy" 2005, nr 1, s. 1068.

${ }^{43}$ Proces karny..., s. 308. 
prawie, jeżeli się stawi, i pozostać na sali, choćby miała zeznawać jako świadek. W tym wypadku sąd przesłuchuje ją w pierwszej kolejności. „Pokrzywdzony nie może skutecznie wnosić o odroczenie rozprawy, usprawiedliwiając swoje niestawiennictwo" ${ }^{44}$. Prawo do wzięcia udziału w rozprawie może obejmować tylko takie prawa i obowiązki, których realizacja nie rodzi konieczności korzystania $\mathrm{z}$ pełnomocnika ${ }^{45}$. Pokrzywdzona osoba starsza jest więc pozbawiona prawa do zadawania pytań osobom przesłuchiwanym czy składania wniosków dowodowych. Może jednak wnosić o zadanie określonego pytania przez sąd z urzędu lub przeprowadzenie z urzędu określonego dowodu. Prawo do udziału w rozprawie pokrzywdzonego odróżnia od publiczności to, że może wziąć udział także w rozprawie, której jawność została wyłączona ${ }^{46}$. Dodatkowo prawo pokrzywdzonej osoby starszej do wzięcia udziału w rozprawie może stać się jej obowiązkiem, jeśli sąd uzna to za celowe, czyli gdy według sądu będzie to miało znaczenie dla wyjaśnienia sprawy i prawidłowego orzekania ${ }^{47}$. Problem powstaje, jeśli pokrzywdzona osoba starsza ze względu na chorobę lub kalectwo nie ma możliwości się stawić. W takim wypadku brakuje przepisu pozwalającego uczestniczyć pokrzywdzonej osobie starszej w rozprawie lub posiedzeniu na odległość.

Pokrzywdzona osoba starsza bez statusu strony ma prawo do dokonania następujących czynności procesowych:

1) wniesienia wniosku o przeprowadzenie postępowania mediacyjnego (art. 23a k.p.k.) ${ }^{48}$;

2) wniesienia wniosku o wyłączenie jawności całości lub części rozprawy, jeśli złożyła wniosek o ściganie (art. 360 § 1 pkt 1 k.p.k.) ${ }^{49}$;

3) sprzeciwienia się wnioskowi o skazanie bez przeprowadzenia rozprawy (art. $343 \S 2$ k.p.k.) $)^{50}$;

4) negocjacji i sprzeciwienia się wnioskowi o dobrowolne poddanie się karze (art. 387 § 2 k.p.k.);

5) wniesienia wniosku o naprawienie szkody (art. 49 k.p.k.) ${ }^{51}$;

6) wniesienia wniosku o prawo do przeglądania akt za zgodą prezesa sądu (art. $156 \S 1$ k.p.k.);

7) obecności przy ogłoszeniu wyroku w związku z tym, że zgodnie z art. 45 ust. 2 konstytucji ogłoszenie wyroku odbywa się publicznie. Jeśli wyrok został

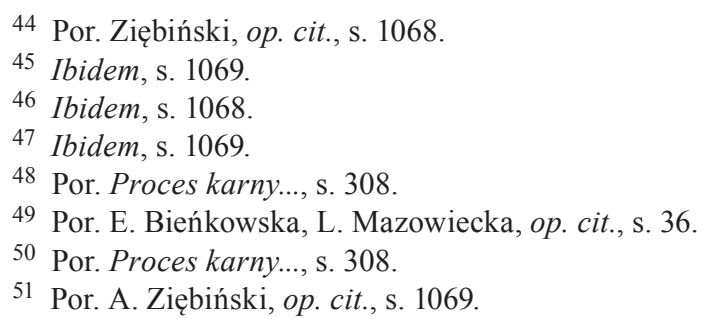


wydany na posiedzeniu, pokrzywdzony może dowiedzieć się o jego treści w sekretariacie sądu, gdzie wyrok powinien zostać wyłożony na 7 dni ${ }^{52}$;

8) doręczenia wyroku, jeżeli przysługuje od niego środek odwoławczy, czyli od wyroku warunkowo umarzającego postępowanie na posiedzeniu (art. 100 $\S 3$ k.p.k. $)^{53}$;

9) wniesienia apelacji od wyroku warunkowo umarzającego postępowanie wydanego na posiedzeniu (art. 444 k.p.k.). Niestety w tak zainicjowanym postępowaniu apelacyjnym nie ma prawa do składania oświadczeń i wniosków czy inicjatywy dowodowej ${ }^{54}$.

Poza samodzielnym reprezentowaniem swoich interesów w postępowaniu karnym przez pokrzywdzoną osobę starszą istnieje możliwość ustanowienia pełnomocnika. Wynika to z unormowania ogólnego prawa osoby niebędącej stroną do ustanowienia pełnomocnika, jeżeli wymagają tego jej interesy w toczącym się postępowaniu, co ocenia sąd, czyli art. 85 k.p.k. Na zasadach ogólnych, wypływających z art. $78 \mathrm{w}$ zw. z art. 88 k.p.k., pokrzywdzona osoba starsza może również wnosić o wyznaczenie obrońcy z urzędu, jeżeli nie jest w stanie ponieść kosztów obrony bez uszczerbku dla niezbędnego utrzymania siebie i rodziny. Jednak jeżeli pokrzywdzony, co może dotyczyć osoby starszej, jest głuchy, niemy, niewidomy, zachodzi uzasadniona wątpliwość, czy stan jego zdrowia psychicznego pozwala na udział w postępowaniu i prowadzenie swoich interesów w sposób rozsądny, to brakuje regulacji obowiązkowego pełnomocnika, chociaż ustawa przewiduje tutaj udział obowiązkowego obrońcy. Oznacza to, że mimo zajścia opisanych przypadków sąd nie sprawdzi, czy pokrzywdzony, w tym pokrzywdzona osoba starsza, występuje z pełnomocnikiem ani w razie jego braku nie ustanowi pełnomocnika z urzędu, tak jak zrobiłby to względem oskarżonego.

Oprócz pełnomocnika pokrzywdzonej osoby starszej jej interesy w procesie może reprezentować także pełnomocnik opiekuna nieporadnej pokrzywdzonej osoby starszej, ustanowionego na podstawie art. $51 \S 3$ k.p.k., o którym była mowa wcześniej. Obaj pełnomocnicy są uprawnieni w ramach ogólnego umocowania do dokonywania wszelkich czynności łączących się z daną sprawą na podstawie art. 91 ustawy z dnia 17 listopada 1964 roku - Kodeks postępowania cywilnego ${ }^{55}$ w zw. z art. 89 k.p.k., w tym do złożenia wniosku o ściganie oraz jego cofnięcia za zgodą sądu do czasu rozpoczęcia przewodu sądowego na pierwszej rozprawie głównej ${ }^{56}$.

52 Por. M. Kupiec, Wplyw zastosowania przepisów art. 100 § 3 k.p.k. i art. 418 a k.p.k. na bieg terminu do złożenia wniosku o sporządzenie i doręczenie uzasadnienia wyroku, „Nowa Kodyfikacja Prawa Karnego" 20, 2006, s. 188.

53 Ibidem.

54 Por. A. Ziębiński, op. cit., s. 1069.

55 Tekst jedn. Dz.U. z 2018 r., poz. 155 ze zm.

56 Postanowienie SN z dnia 23 października 2012, III KK 2/12, OSNKW 2013, Nr 2, poz. 16. 


\section{Uprawnienia pokrzywdzonej osoby starszej ze statusem strony}

Uprawnienia pokrzywdzonej osoby starszej ze statusem strony wykraczają ponad opisane już uprawnienia pokrzywdzonej osoby starszej bez statusu strony. Wynikają one bezpośrednio ze statusu strony i z zasady kontradyktoryjności oraz zasady równości broni (zwanej również zasadą równości stron procesowych). Zostały one przydane pokrzywdzonej osobie starszej-stronie w celu obrony jej interesów w procesie karnym.

W postępowaniu przed sądem pierwszej instancji pokrzywdzona osoba starsza ze statusem strony ma dodatkowo prawo inicjatywy dowodowej ${ }^{57}$, czyli prawo składania wniosków dowodowych, a także prawo aktywnego udziału w przeprowadzaniu dowodów ${ }^{58}$, przede wszystkim zaś prawo zadawania pytań świadkom i biegłym, również prawo wypowiadania się oraz prawo do głosu końcowego ${ }^{59}$. Przysługuje jej także zażalenie na postanowienia wydawane $\mathrm{w}$ trakcie procesu, jeżeli ustawa przewiduje możliwość złożenia zażalenia. W postępowaniu prywatnoskargowym pokrzywdzona osoba starsza jako oskarżyciel może pojednać się z oskarżonym na podstawie art. 492 k.p.k., a także zgodnie z art. 496 k.p.k. odstąpić od oskarżenia przed prawomocnym zakończeniem postępowania, a przed rozpoczęciem przewodu sądowego na pierwszej rozprawie głównej także bez zgody oskarżonego.

Pokrzywdzona osoba starsza ze statusem strony ma prawo do złożenia wniosku o sporządzenie uzasadnienia i doręczenie wyroku wraz z uzasadnieniem, a następnie prawo do zainicjowania postępowania odwoławczego poprzez realizację prawa złożenia apelacji, a także prawo do odpowiedzi na apelację złożoną przez inną stronę procesu ${ }^{60}$. Ma ona też prawo do udziału w postępowaniu apelacyjnym.

Ostatecznie pokrzywdzona osoba starsza ze statusem strony ma prawo do postępowania kasacyjnego. Może więc złożyć kasację, a tym samym zainicjować postępowanie kasacyjne, odpowiedzieć na kasację, jak również wziąć udział w postępowaniu kasacyjnym ${ }^{61}$.

W całym postępowaniu sądowym pokrzywdzona osoba starsza ze statusem strony ma możliwość złożenia wniosku o wyłączenie jawności całości lub części rozprawy, niezależnie od tego, czy składała wniosek o ściganie, czy też nie ${ }^{62}$. Przysługuje jej także bezwzględne prawo dostępu do akt sprawy i prawo do ustanowienia pełnomocnika bez konieczności sprawdzania, czy wymagają tego jej interesy w toczącym się postępowaniu. Zgodnie z poglądem Sądu Najwyższego pokrzywdzona osoba starsza ze statusem strony w postępowaniu sądowym od

57 Por. A. Drozd, Inicjatywa dowodowa pokrzywdzonego w świetle kontradyktoryjnego procesu karnego, „Prokuratura i Prawo” 2014, nr 10, s. 47.

58 Ibidem.

59 Ibidem, s. 55.

60 Por. Proces karny..., s. 173.

61 Ibidem.

62 Por. E. Bieńkowska, L. Mazowiecka, op. cit., s. 36. 
czasu nabycia tego statusu nie może korzystać z pomocy opiekuna ustanowionego na podstawie art. $51 \S 3$ k.p.k. lub jego pełnomocnika ${ }^{63}$. Zasygnalizowany wcześniej problem braku uregulowań obowiązkowego pełnomocnika pokrzywdzonej osoby starszej w wypadku nabycia przez nią statusu strony w postępowaniu sądowym, co wiąże się z większymi uprawnieniami niż posiadane przez pokrzywdzoną osobę starszą bez statusu strony, nabiera na sile. Wszak na skutek zmian starczych pokrzywdzeni mogą utracić wzrok, słuch czy mowę — zmysły tak bardzo potrzebne $\mathrm{w}$ dochodzeniu swoich praw przed sądem. Wzrok pozwala nie tylko swobodnie poruszać się w celu dotarcia do sądu, ale także przeglądać akta, czytać pouczenia lub widzieć zachowania osób występujących na sali rozpraw ${ }^{64}$. Dzięki słuchowi pokrzywdzony może dowiedzieć się, co uczestnicy postępowania mówią podczas rozprawy, a także przyjąć kolejne pouczenia ${ }^{65}$. Mowa pozwala natomiast reagować na składane oświadczenia i wnioski oraz dokonywać czynności, które mogą lub powinny zostać złożone ustnie do protokołu, czyli wypowiadanie się co do wszystkich przeprowadzanych dowodów, zadawanie pytań świadkom lub biegłym czy inicjatywa dowodowa ${ }^{66}$. W odróżnieniu od oskarżonych pokrzywdzone osoby starsze w sytuacji takich ułomności fizycznych nie muszą jednak mieć obowiązkowego pełnomocnika, który dokonałby w ich imieniu czynności procesowych, co może ograniczać korzystanie z praw pokrzywdzonego w postępowaniu przed sądem karnym. Jeśli opisane ułomności fizyczne mają ograniczony stopień, co oznacza tylko częściową utratę wzroku, słuchu lub mowy, to nie przewidziano fakultatywnej kompetencji sądu do ustanowienia obowiązkowego pełnomocnika. Podobna sytuacja związana z brakiem uregulowań obowiązkowego pełnomocnika dotyczy innych przeszkód w obronie własnych interesów przez pokrzywdzonych ludzi starszych, takich jak wątpliwości co do poczytalności lub choroba psychiczna. Natomiast przyznanie oskarżonemu obowiązkowego obrońcy w opisanych sytuacjach zaburza równowagę stron kontradyktoryjnego z założenia postępowania karnego.

\section{Propozycje de lege ferenda}

Wypływające z przedstawionych rozważań propozycje de lege ferenda koncentrują się na uregulowaniach wprowadzających ułatwienia korzystania z uprawnień pokrzywdzonej osobie starszej. Widoczne są braki w tej materii zarówno wśród uregulowań natury ogólnej, deklaratywnej, jak i między unormowaniami szczegółowymi.

63 Postanowienie SN z 23 maja 2013, III KK 52/13, www.sn.pl.

${ }^{64}$ Por. S. Orzechowska, Utomności fizyczne oskarżonego jako podstawa obrony obligatoryjnej, „Ius Novum” 2010, nr 3, s. 93.

65 Ibidem, s. 89.

66 Ibidem, s. 91. 
W zakresie uregulowań natury ogólnej ustanowiony w art. 2 w $\S 1$ w pkt 3 k.p.k. cel procesu karnego, nakazujący uwzględnienie prawnie chronionych interesów pokrzywdzonego, przy jednoczesnym poszanowaniu jego godności, nie odnosi się wprost do wieku pokrzywdzonego. Dlatego należałoby zaproponować rozszerzenie na przykład o takim brzmieniu: ,przepisy niniejszego kodeksu mają na celu takie ukształtowanie postępowania karnego, aby zostały uwzględnione prawnie chronione interesy pokrzywdzonego przy jednoczesnym poszanowaniu jego godności oraz stanu pokrzywdzonego wynikającego z jego wieku, choroby, niepełnosprawności, nieporadności lub sytuacji materialnej”. Deklaracja niedyskryminująca mogłaby zostać dodana również w osobnym przepisie. Chroniłaby ona dodatkowo prawo do sądu i prawo do rzetelnego procesu, przysługujące pokrzywdzonej osobie starszej.

Niewystarczające są również uregulowania szczególne ułatwiające korzystanie z uprawnień pokrzywdzonego. Jak wynika z dotychczasowych rozważań, wprowadzają one jedynie możliwość reprezentowania pokrzywdzonego przez osobę, pod której pieczą konkretna osoba starsza pozostaje. Brakuje więc uregulowania prawa uczestniczenia pokrzywdzonej osoby starszej w rozprawie i posiedzeniu na odległość, realizowanego podobnie do przesłuchania świadka na odległość oraz obowiązkowego pełnomocnika skonstruowanego na wzór obowiązkowej obrony. Ze względu na mogącą wynikać ze starości niepełnosprawność lub chorobę wizyta w sądzie czy zrozumienie pouczeń może wiązać się z dużymi trudnościami. Jednocześnie to nie powinno wykluczać pokrzywdzonej osoby starszej z procesu, w czym mogą pomóc proponowane regulacje. Lepszą gwarancją procesową dla pokrzywdzonej osoby starszej stałaby się także, postulowana w doktrynie w stosunku do wszystkich pokrzywdzonych ${ }^{67}$, zmiana terminu złożenia oświadczenia o występowaniu w procesie w charakterze oskarżyciela posiłkowego lub prywatnego z prekluzyjnego na zawity (przywracalny). W stosunku do pokrzywdzonej osoby starszej postulat ten szczególnie nabiera na sile, ponieważ opisana zmiana pozwoliłaby na występowanie w procesie jako strony i korzystanie z uprawnień pokrzywdzonej osoby starszej, która uchybiłaby terminowi nie z własnej winy, lecz na skutek zdarzeń losowych, na przykład chorób występujących częściej w podeszłym wieku, i nadal wyraża chęć zostania stroną procesu. Co prawda, postępowanie takie mogłoby trwać dłużej, ponieważ w wypadkach, w których nie występowałby oskarżyciel publiczny, nie można byłoby pochopnie umorzyć postępowania z powodu braku skargi uprawnionego oskarżyciela, jednakże szybkie zakończenie procesu poprzez jego umorzenie może nie być satysfakcjonujące dla pokrzywdzonej osoby starszej i prowadzić do jej wykluczenia z postępowania.

67 Por. M. Piech, Glosa do wyroku TK z dnia 8 stycznia 2013 r., K 18/10, „Państwo i Prawo” 2015, nr 1, s. 122; Ł. Supera, D. Wyszkowski, Subsydiarny akt oskarżenia w ujęciu konstytucyjnym, „Palestra” 2016, nr 7-8, s. 73. 
Proponowane regulacje zwiększyłyby w stosunku do pokrzywdzonej osoby starszej poziom realizacji jej uprawnień w postępowaniu przed sądem karnym, zależnych i niezależnych od statusu strony. Dodatkowe gwarancje nie uprzywilejowywałyby nadmiernie tej grupy, lecz dopiero przywracałyby równość między ludźmi ze względu na wiek.

\section{Zakończenie}

W kontekście obecnej tendencji demograficznej nie można uznać za nieistotny problemu uczestniczenia pokrzywdzonych ludzi starszych w postępowaniach przed sądem karnym. Tymczasem w prawie karnym procesowym szczególnie zostały potraktowane dzieci, nie zwracając uwagi na to, że grupa ludzi dorosłych również jest zróżnicowana. Ludzie pełnoletni jako pokrzywdzeni w postępowaniu karnym, niezależnie od wieku, tak samo stają się osobami pokrzywdzonymi i tak samo nabywają status strony, a także mają takie same uprawnienia. Jedyną różnicą jest możliwość wykonywania praw nieporadnej pokrzywdzonej osoby starszej przez osobę, pod której pieczą pokrzywdzony pozostaje.

Bezradność, problemy ze zrozumieniem postępowania przed sądem karnym, stan zdrowia i następujące $\mathrm{z}$ wiekiem ułomności fizyczne pokrzywdzonych osób starszych stawiają przed sądami szczególne wymagania oraz generują dodatkowe problemy, które muszą być rozstrzygnięte w postępowaniu karnym, tym bardziej że niedostosowanie procesu karnego do potrzeb pokrzywdzonej osoby starszej może prowadzić do jej wykluczenia i dyskryminacji oraz ignorowania potrzeb seniorów ${ }^{68}$. Opisywany problem powinien zostać rozwiązany systemowo. W tym celu ludzie starsi potrzebują programów pomocowych dotyczących występowania przed sądem karnym w przypadku stania się ofiarą przestępstwa ${ }^{69}$. Innymi słowy, względem ludzi starszych powinna być wprowadzona „organizacja poradnictwa życiowego i prawno-społecznego wraz z systemem interwencji w urzędach i instytucjach"70. Umożliwieniu korzystania przez ludzi starszych z ich praw w procesie miały służyć również proponowane w opracowaniu propozycje de lege ferenda, dotyczące deklaracji niedyskryminacji osób starszych w procesie karnym oraz rozwiązań szczegółowych koncentrujących się wokół umożliwienia uczestniczenia w rozprawie lub posiedzeniu na odległość, wprowadzenia obowiązkowego pełnomocnika oraz zmiany prekluzyjnych terminów do złożenia oświadczenia o udziale w procesie $\mathrm{w}$ charakterze strony na zawite. Wprowadzenie tego wymaga interwencji ustawodawcy, tymczasem ludzie starsi nie mają lobby, które dbałoby o ich interesy prawne ${ }^{71}$. Dodatkowo obowiązkowe pełnomocnictwo pokrzywdzonych osób starszych wiąże się $\mathrm{z}$ koniecznością poczynienia nakładów finansowych na pełnomocników z urzędu.

68 B. Mikołajczyk, op. cit., s. 42.

69 E. Bieńkowska, op. cit., s. 117.

70 E. Rosset, Człowiek stary a społeczeństwo, „Studia Demograficzne” 1971, nr 25, s. 41.

71 E. Bieńkowska, op. cit., s. 117. 
W każdym stanie prawnym to sądy powinny traktować pokrzywdzone osoby starsze w taki sposób, aby nie poczuły się one pokrzywdzone — nie dość, że przez sprawcę, to jeszcze dodatkowo przez organy mające wymierzać sprawiedliwość, czyli aby nie zaznały tak zwanej wiktymizacji wtórnej. Może to się stać wyrazem solidarności między pokoleniami.

\section{Bibliografia}

\section{Literatura}

Bieńkowska E., Osoby starsze grupa o podwyższonym stopniu ryzyka wiktymizacji, „Ruch Prawniczy, Ekonomiczny i Socjologiczny" 1999, z. 1.

Bieńkowska E., Mazowiecka L., Uprawnienia pokrzywdzonego przestępstwem, Warszawa 2009.

Boratyńska K.T., Górski A., Sakowicz A., Ważny A., Kodeks postępowania karnego. Komentarz, Warszawa 2012.

Czapska J., Zapobieganie wiktymizacji ludzi starszych, „Ruch Prawniczy, Ekonomiczny i Socjologiczny" 1999, z. 1.

Drozd A., Inicjatywa dowodowa pokrzywdzonego w świetle kontradyktoryjnego procesu karnego, „Prokuratura i Prawo” 2014, nr 10.

Grzeszczyk W., Kodeks postępowania karnego. Komentarz, Warszawa 2012.

Halicka M., Halicki J., Przemoc wobec ludzi starych, Białystok 2010.

Hate Crime Report 2014/2015 and 2015/16, Crown Prosecution Service, London, July 2016.

Kupiec M., Wptyw zastosowania przepisów art. 100 \$ 3 k.p.k. i art. 418 a k.p.k. na bieg terminu do złożenia wniosku o sporzadzenie i doręczenie uzasadnienia wyroku, „Nowa Kodyfikacja Prawa Karnego" 20, 2006.

Mikołajczyk B., Międzynarodowa ochrona praw osób starszych, Warszawa 2012.

Orzechowska S., Ułomności fizyczne oskarżonego jako podstawa obrony obligatoryjnej, „Ius Novum" 2010, nr 3.

Paprzycki L.K., Prawa i obowiąki pokrzywdzonego w postępowaniu przed sądem karnym pierwszej instancji - zarys problematyki, „Palestra” 2000, nr 2-3.

Piech M., Glosa do wyroku TK z dnia 8 stycznia 2013 r., K 18/10, „Państwo i Prawo” 2015, nr 1.

Proces karny, red. J. Skorupka, Warszawa 2017.

Przyjemski S.M., Pokrzywdzony w roli oskarżyciela positkowego, „Wojskowy Przegląd Prawniczy” 2005, nr 3.

Rosset E., Człowiek stary a społeczeństwo, „Studia Demograficzne” 1971, nr 25.

Supera Ł., Wyszkowski D., Subsydiarny akt oskarżenia w ujęciu konstytucyjnym, „Palestra” 2016, nr 7-8,

Świecki D., Czynności procesowe obrońcy i petnomocnika w sprawach karnych, Warszawa 2011.

Ziębiński A., Prawo pokrzywdzonego do wzięcia udziału w rozprawie, „Monitor Prawniczy” 2005, nr 1.

\section{Inne źródła}

Europejska Konwencja o Ochronie Praw Człowieka i Podstawowych Wolności sporządzona w Rzymie dnia 4 listopada 1950 roku (Dz.U. z 1993 r. Nr 61, poz. 284).

Karta Praw Podstawowych z dnia 7 grudnia 2000 roku, podpisana ponownie dnia 12 grudnia 2007 roku (Dz.Urz. UE z 2016 r., C, 202, s. 389).

Konstytucja Rzeczypospolitej Polskiej z dnia 2 kwietnia 1997 roku (Dz.U. Nr 78, poz. 483 ze zm.). 
Międzynarodowy Pakt Praw Obywatelskich i Politycznych otwarty do podpisu w Nowym Jorku dnia 19 grudnia 1966 roku (Dz.U. z 1977 r. Nr 38, poz. 167).

Rezolucja ONZ nr 46/91: Zasady działania ONZ na rzecz osób starszych (tekst polski: http://www. tus.org.pl/uploads/dokumenty/zasady_dzialania_onz_na_rzecz_osob_starszych.pdf.

Traktat o Unii Europejskiej z dnia 7 lutego 1992 roku (wersja skonsolidowana: Dz.Urz. UE z 2016 r. C, 202, s. 13).

Traktat o funkcjonowaniu Unii Europejskiej z dnia 25 marca 1957 roku (wersja skonsolidowana: Dz.Urz. UE z 2016 r. C, 202, s. 47).

Ustawa z dnia 11 września 2015 roku o osobach starszych (Dz.U. poz. 1705).

Ustawa z dnia 17 listopada 1964 roku - Kodeks postępowania cywilnego (tekst jedn. Dz.U. z 2018 r., poz. 155 ze zm.).

Ustawa z dnia 6 czerwca 1997 roku — Kodeks postępowania karnego (tekst jedn. Dz.U. z 2016 r., poz. 1749 ze zm.).

\section{Orzecznictwo}

Postanowienie SN z dnia 25 września 2003 roku., III KZ 36/03, OSNwSK 2003, Nr 1, poz. 2046. Postanowienie SN z dnia 23 października 2012 roku, III KK 2/12, OSNKW 2013, Nr 2, poz. 16. Postanowienie SN z 23 maja 2013 roku, III KK 52/13, www.sn.pl.

Postanowienie SN z dnia 12 kwietnia 2016 roku, V KK 29/16, LEX nr 2046365.

\section{Elderly person as an aggrieved party in the criminal court proceedings}

\section{Summary}

In the context of current demographic trends the problem of participating of aggrieved elderly people in the criminal court proceedings cannot be considered negligible. At present, in the criminal law process in a special way children have been treated, paying no attention to the fact that a group of adults is also varied. Thus, adult people as aggrieved party in criminal proceedings, regardless of age just become aggrieved persons, and so acquire the status of the parties and have the same rights. The only difference is the ability to exercise the rights of an elderly helpless aggrieved person by the person under whose care the victim remains.

Helplessness, difficulty understanding court proceedings, sickliness and the following age other physical disability, aggrieved elderly persons generate particular demands from the courts and some additional problems which must be resolved in criminal proceedings. The more so that failure in the criminal process to the needs of the aggrieved elderly person can lead to the exclusion and discrimination. This is a category of ignoring the needs of the elderly. Law should enable older people to exercise their rights in the process. Described problem should be resolved systemic. For this purpose, the elderly are in need of assistance programs, concerning appearance before a criminal court in the case of becoming a victim of crime. In other words, with respect to the elderly should be introduced organizations aimed at counseling, legal and social intervention with the system in offices and institutions. The de lege ferenda proposals regarding declarations of non-discrimination of older people in the penal process and detailed solutions focusing on allowing participation in a hearing at a distance, institution of a compulsory attorney and changing deadllines to terms which are resettable were also intended to enable older people to use their rights in the process better. The introduction of this requires the intervention of the legislature, while older people do not have a lobby that cares about their interests before the authorities. In addition, the obligation mandatory for aggrieved elderly people require make funding for representatives from office. 
However in every legal system, the courts should treat the aggrieved elderly people in such a way that they do not feel aggrieved, not only by the perpetrator, but also by organs that are supposed to administer justice, what means the victims should not expereince the so-called secondary victimization. This may become an expression of solidarity between generations. 